\title{
The Relationship between Chemiosmotic Parameters and Sensitivity to Anions and Organic Acids in the Acidophile Thiobacillus ferrooxidans
}

\author{
By BRIAN ALEXANDER, SARAH LEACH AND W. JOHN INGLEDEW* \\ Department of Biochemistry and Microbiology, University of St Andrews, St Andrews, \\ Fife $K Y 169 A L, U K$
}

(Received 15 September 1986; revised 16 December 1986)

\begin{abstract}
We investigated the relationships between the trans-cytoplasmic-membrane chemiosmotic parameters, viz. the membrane potential and the $\mathrm{pH}$ difference, and the toxicity of anions and organic acids in the acidophile Thiobacillus ferrooxidans. Organic acids accumulated in the cytoplasm in response to the transmembrane $\mathrm{pH}$ difference and inorganic anions could be caused to accumulate in response to the membrane potential. The distribution of the organic acids was unaffected by the membrane potential and that of the anions was not influenced by the $\mathrm{pH}$ difference. These accumulations may be toxic because of a direct effect of a high concentration of the anion in the cytoplasm or by acidification of the cytoplasm. The point of inhibition of respiration was at the level of the respiratory chain cytochrome oxidase when $\mathrm{Fe}(\mathrm{II})$ was the respiratory substrate.
\end{abstract}

\section{INTRODUCTION}

Thiobacillus ferrooxidans is capable of growth by oxidation of $\mathrm{Fe}(\mathrm{II})$ iron or inorganic sulphur species, using oxygen as respiratory oxidant. This growth occurs in an acidic environment and is itself acidogenic when the substrate is native pyrite. During these processes the internal $\mathrm{pH}$ $\left(\mathrm{pH}_{\mathrm{in}}\right)$ of the cell is maintained at approximately 6.5 while the $\mathrm{pH}$ of the suspending medium $\left(\mathrm{pH}_{\text {out }}\right)$ may be as low as 1.0 (Cox et al., 1979). The $\mathrm{pH}$ difference $(\Delta \mathrm{pH})$ across the cytoplasmic membrane is one component of the proton-electrochemical potential $(\Delta p)$; the other component is the membrane potential $(\Delta \psi)$. These forces are related thus: $\Delta p=\Delta \psi-59 \Delta \mathrm{pH}$ (Mitchell, 1966). $\Delta p$ is the initially conserved form of the energy available from the redox potential difference donor and acceptor substrates in the functioning respiratory chain. The magnitude of the $\Delta p$ reflects the energy status of the cell and is thus variable. However, of the two components which make up the $\Delta p$, the $\Delta \mathrm{pH}$ component is not (and cannot be for physiological reasons) very variable under normal circumstances. $\Delta \psi$ varies, in response to the energy state of the cell, from close to zero to a value which is large and approximately equal and opposite to the $\Delta \mathrm{pH}$, i.e. when the cell is 'de-energized', $\Delta p$ must be zero (Cox et al., 1979).

Organic acids, in general, are deleterious to $\mathrm{Fe}(\mathrm{II})$ oxidation and cell viability. It has been suggested that one major factor contributing to the effectiveness of an organic acid in inhibiting $\mathrm{Fe}(\mathrm{II})$ oxidation is the relative electronegativity of the species, and that they act (i) via a direct effect on the $\mathrm{Fe}$ (II) oxidizing enzyme system; (ii) by reacting abiologically with $\mathrm{Fe}$ (II) outside the cell; and (iii) by non-selectively disrupting the cell envelope or membrane (Tuttle \& Dugan, 1976; Tuttle et al., 1977). We proposed that the toxicity of 'weak' acids can, in general, be ascribed to their accumulation in the cell matrix in response to the $\mathrm{pH}$ difference between the cytoplasm and the supporting medium (Ingledew, 1982). The distribution of weak acids across a membrane separating phases of different $\mathrm{pH}$ is a well-documented physical process, the

Abbreviations: $\Delta \mathrm{pH}$, transmembrane $\mathrm{pH}$ difference; $\Delta \psi$, membrane potential; $\Delta p$, proton-electrochemical potential. 
condition for the following treatment being that only the fully protonated form is significantly membrane-permeable. The concentrations of the anionic form in the two phases are related by a consideration of the Henderson-Hasselbalch equation in each phase and equating the internal and external concentrations of the undissociated form. For a monobasic acid the relationship of accumulation to $\mathrm{pH}_{\mathrm{in}}, \mathrm{pH}_{\text {out }}$ and $\mathrm{p} K_{\mathrm{a}}$ is given by

$$
\mathrm{pH}_{\text {in }}=\mathrm{p} K_{\mathrm{a}}+\log _{10}\left[A_{\text {in }} / A_{\text {out }}\left(1+10^{\mathrm{pH}_{\text {out }} \mathrm{p} K_{\mathrm{a}}}\right)-1\right]
$$

where $A_{\text {in }}$ and $A_{\text {out }}$ are the concentrations of the anionic form inside and outside the cell (Addanki et al., 1968). For a dibasic acid, if $\mathrm{p} K_{\mathrm{a}_{1}}$ and $\mathrm{p} K_{\mathrm{a}_{2}}$ are the same the accumulation ratio is squared when compared to a monobasic acid with the same $\mathrm{p} K_{\mathrm{a}}$ (et seq. for polybasic acids). Accumulation of the anion of the weak acid could be toxic in three ways: a simple concentration effect (which can be very large), an acidification of the cell matrix by the protons which accompany the accumulation, or osmotic damage to the cytoplasmic membrane. Thus, all else being equal, the toxicity of organic acids to $T$. ferrooxidans can be predicted to be related to their basicity, $\mathrm{p} K_{\mathrm{a}}$ values, the absence of positively charged groups (which may affect distribution and membrane permeability) and the $\mathrm{pH}$ of the suspending medium. In this paper we present evidence in support of this proposal.

As $T$. ferrooxidans is used in the leaching of minerals from different ore deposits there have been many studies on the effects of inorganic ions on cell growth and $\mathrm{Fe}$ (II) oxidation (for references see Ingledew, 1982). In general, $T$. ferrooxidans is unusually resistant to cations but relatively sensitive to anions. All inorganic anions are less effective than $\mathrm{SO}_{4}^{2-}$ at supporting $\mathrm{Fe}(\mathrm{II})$ oxidation or cell growth. This has led to the suggestion that $\mathrm{SO}_{4}^{2-}$ is directly involved in the mechanism of $\mathrm{Fe}$ (II) oxidation and models of $\mathrm{Fe}$ (II) oxidation incorporating a direct role for $\mathrm{SO}_{4}^{2-}$ have been proposed (Dugan \& Lundgren, 1965; Lazaroff, 1983). $\mathrm{SO}_{4}^{2-}$ does, as any dominant anion will, have a direct physicochemical effect on the mid-point potential of the $\mathrm{Fe}(\mathrm{II}) / \mathrm{Fe}$ (III) couple; these effects are, however, due to complexation and do not necessarily imply a role in the reaction mechanism. Noting that the oxidation of sulphur and its reducing oxy-anions by $T$. ferrooxidans is also sensitive to the anionic composition of the medium (Razzell \& Trussell, 1963; Lazaroff, 1977), we have sought a general physiological explanation for the toxicity of anions. On the basis of our findings we propose that one of the ways in which inorganic anions are toxic is via the accumulation of the anion into the cell cytoplasm as a result of the combination of a finite permeability of the cytoplasmic membrane to the charged anion and a membrane potential $(\Delta \psi)$ positive inside, i.e. the anions tend to respond to the membrane potential as lipophilic ions [the $\Delta \psi$ and distribution are related by $\Delta \psi=(59 / n) \log _{10}\left(A_{\text {in }}^{n-} / A_{\text {out }}^{n-}\right)$ ]. In the case of an acidophile the $\Delta \psi$ is often positive inside, because, with the need to maintain the cytosol at neutrality, the $\Delta \mathrm{pH}$ is very large (Cox et al., 1979; Matin et al., 1982).

The respiratory chain of $T$. ferrooxidans is short and comprises a blue copper protein, cytochromes $c$, and the oxidase cytochrome(s) $a_{1}$ (Ingledew, 1982). Organic acids, and under appropriate conditions anions, inhibit the respiratory chain, and we suggest this is by acidification of the cytoplasm. We have determined, herein, the site of inhibition to be the terminal $\mathrm{O}_{2}$-reducing reaction of the respiratory chain. This finding is consistent with earlier suggestions that most of the respiratory chain components involved in $\mathrm{Fe}$ (II) oxidation are located periplasmically or on the outer surface of the cytoplasmic membrane, and that only the oxidase is in contact with the cytoplasm (Ingledew et al., 1977).

\section{METHODS}

Growth and harvesting. T. ferrooxidans (strain NCIB 8455) cells were grown at room temperature in a 601 chemostat, sparged with air, and at a dilution rate of approximately $0.02 \mathrm{~h}^{-1}$. The medium contained $180 \mathrm{~mm}-$ $\mathrm{FeSO}_{4}, 37.5 \mathrm{mM}-\mathrm{H}_{2} \mathrm{SO}_{4}, 0.2 \mathrm{mM}-\mathrm{KH}_{2} \mathrm{PO}_{4}, 1 \mathrm{~mm}-\left(\mathrm{NH}_{4}\right)_{2} \mathrm{SO}_{4}$ plus $0.2 \mathrm{ml} \mathrm{l}^{-1}$ of a salts solution (Cobley \& Haddock, 1975). The cells were harvested by passage through an MSE continuous-flow rotor operating in an MSE 18 centrifuge at 17000 r.p.m. at a flow rate of approximately $200 \mathrm{ml} \mathrm{min}^{-1}$. The cells were separated from a ferric hydroxysulphate-unhydrated ferric oxide layer (limonite) and washed twice in $10 \mathrm{~mm}-\mathrm{H}_{2} \mathrm{SO}_{4}, \mathrm{pH} 1 \cdot 8$, and twice in $50 \mathrm{mM}-\mathrm{Na}_{2} \mathrm{SO}_{4}$. Cells (3-5 $\mathrm{g}$ wet wt) were then resuspended in appropriate buffer for experimentation and used fresh.

Measurement of $\Delta p H$ and $\Delta \psi$. This was done essentially as described by Nicholls (1974) but modified by 
separating the cells by centrifugation through silicone oil (Rottenberg, 1979). The oil used was BDH silicone fluid 550 (GLC grade). The distribution across the cytoplasmic membrane of $\left[{ }^{3} \mathrm{H}\right]$ acetic acid and $\left[{ }^{14} \mathrm{C}\right]$ chloroacetic acid $(\Delta \mathrm{pH})$, and $\left[{ }^{14} \mathrm{C}\right]$ thiocyanate $(\Delta \psi)$, was determined. Initially, $\left[{ }^{3} \mathrm{H}\right]$ acetate was used to determine the $\Delta \mathrm{pH}$; however, it became apparent that $\mathrm{pH}_{\text {in }}$ was, in some cases, declining to values close to the $\mathrm{p} K_{\mathrm{a}}$ of acetic acid (4.75) thus giving accumulation ratios that were too low for accurate determination of $\mathrm{pH}_{\mathrm{in}}$. Chloroacetic acid $\left(\mathrm{p} K_{\mathrm{a}}=2.86\right)$ was therefore also used to determine the $\Delta \mathrm{pH} .{ }^{3} \mathrm{H}_{2} \mathrm{O}$ was used as a reference isotope with the ${ }^{14} \mathrm{C}$ labelled probes; $\left[{ }^{14} \mathrm{C}\right]$ sucrose was used with the ${ }^{3} \mathrm{H}$-labelled probes. The suspending buffer normally used was $20 \mathrm{~mm}-\beta$-alanine sulphate ( $\mathrm{pH} \mathrm{3.0)}$, together with the specified organic acids and cells (approximately $1 \mathrm{mg}$ protein $\left.\mathrm{ml}^{-1}\right)$. For $\Delta \mathrm{pH}$ measurement $0.075 \mu \mathrm{Ci} \mathrm{ml}^{-1}\left(2.775 \mathrm{kBq} \mathrm{ml}^{-1}\right)\left[{ }^{14} \mathrm{C}\right.$ chloroacetate (normally $\left.1 \mu \mathrm{M}\right)$ and $0.5 \mu \mathrm{Ci} \mathrm{ml}^{-1}\left(18.5 \mathrm{kBq} \mathrm{ml}^{-1}\right){ }^{3} \mathrm{H}_{2} \mathrm{O}$ were used. For measurement of $\Delta \psi\left[{ }^{14} \mathrm{C}\right]$ thiocyanate $\left[0 \cdot 2 \mu \mathrm{Ci} \mathrm{ml}^{-1}\right.$ $\left.\left(7.4 \mathrm{kBq} \mathrm{ml}^{-1}\right) ; 7 \mu \mathrm{M}\right]$ and ${ }^{3} \mathrm{H}_{2} \mathrm{O}\left[0.5 \mu \mathrm{Ci} \mathrm{ml}^{-1}\left(18.5 \mathrm{kBq} \mathrm{ml}^{-1}\right)\right]$ were used. A suspension $(250 \mu \mathrm{l})$ containing isotopes and approximately $0.25 \mathrm{mg}$ (protein) of cells was used for each determination and placed in an Eppendorf tube. The Eppendorf tube contained, in the bottom, $50 \mu \mathrm{l}$ of a dinonyl phthalate/silicone oil $(45: 55, \mathrm{v} / \mathrm{v}) \mathrm{mixture}$. The tubes were spun in an Eppendorf bench centrifuge at $13800 \mathrm{~g}$ for $1 \mathrm{~min}$. The cells separated from the supernatant, pelleting through the oil. The supernatant was aspirated off, and $1 \mathrm{ml}$ of distilled water was added to wash the pellet and tube. This was then aspirated off with the oil, leaving the pellet. SDS $(50 \mu l ; 5 \mathrm{mM})$ was then added and the tubes were incubated at $60^{\circ} \mathrm{C}$ for $2 \mathrm{~h}$ to solubilize the pellets. Scintillation fluid $(1.2 \mathrm{ml}$; toluene/Triton $\mathrm{X}-100,2: 1, \mathrm{v} / \mathrm{v}$ ) was added to each tube and the tubes placed in glass scintillation vials for scintillation counting. Samples from the original incubation and samples from incubations using cells denatured by heat treatment were also counted. In all incubations each determination was made in triplicate.

Measurement of $\mathrm{NO}_{3}^{-}$distribution. This was done by using a similar procedure to that used for the determination of $\Delta \psi$ by isotope distribution, except that the $\mathrm{NO}_{3}^{-}$concentrations in the pellet and supernatant were assayed chemically (colorimetrically) using the Szechrome NAS method (Polysciences Inc., Paul Valley Industrial Park, Warrington, PA 18976, USA). The values for the internal concentration of $\mathrm{NO}_{3}^{-}$were calculated both from the concentration of the anion in the matrix and from the loss of the anion from the supernatant; the values were in good agreement.

Matrix volume. This was determined from the difference between the $\left[{ }^{14} \mathrm{C}\right]$ sucrose permeable space and the ${ }^{3} \mathrm{H}_{2} \mathrm{O}$ permeable space (Rottenberg et al., 1972). The matrix volume was found to be $2 \cdot 3 \mu \mathrm{l}\left(\mathrm{mg}\right.$ protein) ${ }^{-1}$. This result is in good agreement with that of Cox et al. (1979), who recorded a matrix volume of $2.4 \mu \mathrm{l}$ (mg protein) ${ }^{-1}$ for T. ferrooxidans.

Liquid nitrogen temperature spectrophotometry. Liquid nitrogen temperature optical difference spectra of cells in various respiratory states were obtained using a split-beam instrument constructed in the workshops of this department. The optical path length was $0.2 \mathrm{~cm}$. The steady-state level of cytochrome reduction in control and experimental incubations was studied by comparison of the steady state minus oxidized difference spectra after freeze-clamping of the steady-state condition, and by comparison with fully reduced minus oxidized spectra. The cuvette holder consisted of an aluminium spade with two compartments of approximately $1 \mathrm{ml}$ volume. Appropriate media containing cells $\left(4 \mathrm{mg}\right.$ protein $\left.\mathrm{ml}^{-1}\right)$ were placed in each cuvette. One cuvette was oxidized $\left(\mathrm{H}_{2} \mathrm{O}_{2}\right)$; to the other substrate $\left(5 \mathrm{mM}-\mathrm{FeSO}_{4}\right)$ was added. The samples were frozen by immersion after mixing (steady-state) or after a period to allow anaerobiosis to occur (fully reduced).

Assays. Respiratory activities were assayed in a Clark oxygen electrode at $30^{\circ} \mathrm{C}$. Protein was measured by the method of Lowry with the inclusion of $1 \%$ SDS; bovine serum albumin was used as standard.

Bovine serum albumin, 2,4-dinitrophenol and $\beta$-alanine sulphate were from Sigma. All other chemicals were of AnalaR grade and were supplied by BDH. Radioisotopes and scintillation fluid (United Technologies Packard toluene scintillant) were from Amersham.

\section{RESULTS AND DISCUSSION}

The two forces of the $\Delta p$ can affect the distribution of an anion in two ways : (i) as a 'weak' acid when the uncharged form is permeable and is present at a finite concentration, and (ii) electrophoretically, when the charged form is permeable. In the former mechanism accumulation is driven by the $\Delta \mathrm{pH}$ and in the latter by the $\Delta \psi$. These two mechanisms can be distinguished because of the acidophilic nature of the bacterium which allows the magnitude of the $\Delta \psi$ to be varied from close to $0 \mathrm{mV}$ to greater than $150 \mathrm{mV}$, positive inside, under conditions which alter the $\Delta \mathrm{pH}$ little (Cox et al., 1979).

\section{Effects of anions}

The anions used in this study are listed in Table 1, with the approximate concentration of anion required to inhibit $\mathrm{Fe}(\mathrm{II})$ oxidation by $50 \%$ in the presence and absence of uncoupler at 


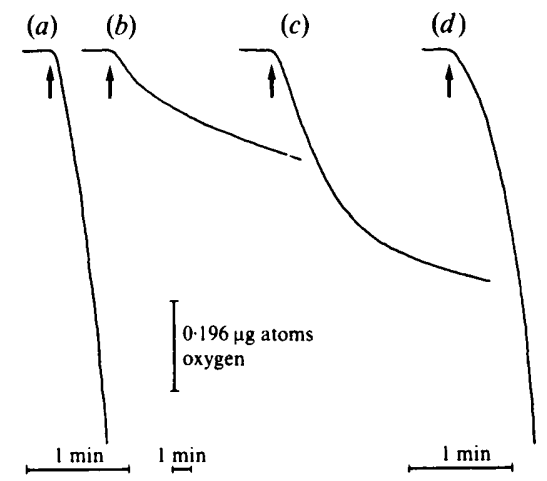

Fig. 1. Clark oxygen electrode traces showing the effect of $\mathrm{Br}^{-}$ions on the oxidation of $\mathrm{Fe}(\mathrm{II})$ by $T$. ferrooxidans under different conditions. (a) Control; $100 \mathrm{mM}-\mathrm{Na}_{2} \mathrm{SO}_{4}$ and $25 \mu \mathrm{M}-\mathrm{DNP}$ in $4 \mathrm{ml}$ buffer. Substrate $\left(2 \mathrm{mM}^{-} \mathrm{FeSO}_{4}\right)$ was added where indicated (arrow) after $2 \mathrm{~min}$ preincubation of cells and buffer. (b) Substrate added last; $100 \mathrm{~mm}-\mathrm{NaBr}$ and $25 \mu \mathrm{M}$-DNP were placed in the vessel. Cells and buffer were preincubated for $2 \mathrm{~min}$ before the addition of $2 \mathrm{mM}-\mathrm{FeSO}_{4}$ (arrow). Note the chart speed is one-sixth that in the other traces. (c) Cells added last; $100 \mathrm{~mm}-\mathrm{NaBr}, 25 \mu \mathrm{M}-\mathrm{DNP}$ and $2 \mathrm{mM}-\mathrm{FeSO}_{4}$ were placed in the vessel. Respiration was initiated by the addition of cells (arrow). (d) No uncoupler; $100 \mathrm{~mm}-\mathrm{NaBr}$ and cells were preincubated for $2 \mathrm{~min}$ before the addition of $2 \mathrm{mM}^{-\mathrm{FeSO}_{4}}$ where indicated (arrow). All incubations were at $30^{\circ} \mathrm{C}$ in a $4 \mathrm{ml}$ vessel. The basic buffer was $20 \mathrm{~mm}-\beta$-alanine sulphate, $\mathrm{pH} 3.0$, in all incubations, and the cells were added to $0.25 \mathrm{mg}$ protein $\mathrm{ml}^{-1}$.

\section{Table 1. Anion inhibition of $\mathrm{Fe}(\mathrm{II})$ respiration in $\mathrm{T}$. ferrooxidans}

$Q$ is the nominal charge per $\mathrm{nm}^{2}$ of ion surface area. Values are calculated from data from The Handbook of Chemistry \& Physics (Boca Raton: CRC Press). The $I_{50}$ values for $\mathrm{Fe}(\mathrm{II})$ oxidation were determined with respect to the $\mathrm{SO}_{4}^{2-}$ controls of similar ionic strength; this did not necessarily correspond to the half-maximum rate as some ions were found to stimulate respiration at low concentrations. Rates of $\mathrm{O}_{2}$ consumption were measured as described in Methods. DNP, where present, was at $25 \mu \mathrm{M}$. The sodium salts of the anions were used; the $\mathrm{pH} 3.0$ buffer was $20 \mathrm{~mm}-\beta$-alanine sulphate and the basic pH 0.94 buffer was $100 \mathrm{~mm}-\mathrm{H}_{2} \mathrm{SO}_{4}$. NA, Not assayed.

\begin{tabular}{|c|c|c|c|c|c|c|}
\hline \multirow[b]{3}{*}{ Anion } & \multirow[b]{3}{*}{$Q$} & \multirow[b]{3}{*}{ Addition } & \multicolumn{4}{|c|}{$I_{50}(\mathrm{mM})$} \\
\hline & & & \multicolumn{2}{|c|}{ pH 0.94} & \multicolumn{2}{|c|}{ pH 3.0} \\
\hline & & & None & DNP & None & DNP \\
\hline $\begin{array}{l}\mathrm{SO}_{4}^{2-} \\
\mathrm{Cl}^{-} \\
\mathrm{Br}^{-}\end{array}$ & $\begin{array}{l}3 \cdot 1 \\
2 \cdot 4 \\
2 \cdot 0\end{array}$ & & $\begin{array}{l}- \\
10 \\
10\end{array}$ & $\begin{array}{c}- \\
0.5 \\
0.5\end{array}$ & $\begin{array}{c}- \\
150 \\
120\end{array}$ & $\begin{array}{l}- \\
1 \\
7\end{array}$ \\
\hline $\mathrm{I}^{-}$ & 1.6 & & $\mathrm{NA}$ & NA & NA & NA \\
\hline $\mathrm{NO}_{3}^{-}$ & 1.6 & & 1 & 0.5 & 25 & $0 \cdot 1$ \\
\hline
\end{tabular}

pH 3.0 and $\mathrm{pH} 0.94$. $\mathrm{NO}_{3}^{-}, \mathrm{Cl}^{-}, \mathrm{Br}^{-}$and $\mathrm{I}^{-}$all have a single charge whereas $\mathrm{SO}_{4}^{2-}$, which is the least inhibitory anion, and used as control, has a double charge. Of the halides $\mathrm{I}^{-}$is the largest ion, and in the presence of $I_{2}$ this will tend to form larger (and more permeant) $I_{n}^{-}$species. Traces of $\mathrm{Fe}(\mathrm{III})$ present will oxidize some of the $\mathrm{I}^{-}$to $\mathrm{I}_{2}$, which is why $\mathrm{I}^{-}$was not tested for effects on $\mathrm{Fe}(\mathrm{II})$ respiration. The surface charge $(Q)$ is a parameter that is calculated from the ionic surface area of the unhydrated ion and the sum of the modules of the individual charges. It provides a correlation with the toxicity of the anion and its ability to collapse $\mathrm{pH}_{\mathrm{in}}$. It can be seen from a comparison of the concentrations of anions required for $50 \%$ inhibition of oxidation that the presence of uncoupler (the protonophore DNP) greatly enhances the toxicity of the anions tested

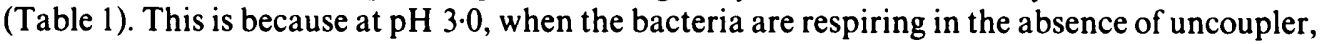
the $\Delta \psi$ will be approximately $-40 \mathrm{mV}$ inside (tends to electrophoretically exclude anions), whereas in the presence of uncoupler the $\Delta \psi$ will approach $+180 \mathrm{mV}$ inside, tending to 

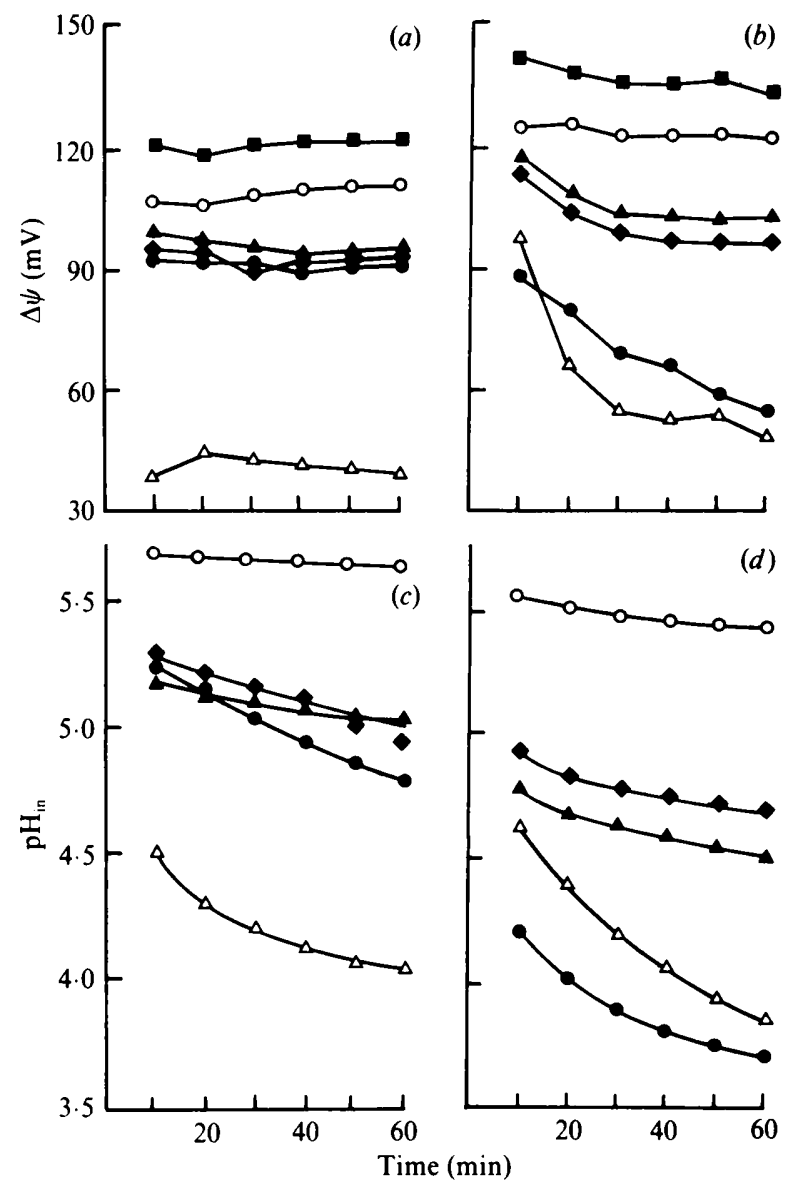

Fig. 2. Effect of inorganic anions on $\mathrm{pH}_{\text {in }}$ and $\Delta \psi$ in non-respiring $T$. ferrooxidans cells. $(a, b)$ Effect of anions on $\Delta \psi:(a)$ coupled; $(b)$ uncoupled $\left(+25 \mu \mathrm{M}\right.$-DNP). $(c, d)$ Effect of anions on $\mathrm{pH}_{\mathrm{in}}$ : $(c)$ coupled; (d) uncoupled $(+25 \mu \mathrm{M}$-DNP). The concentration of the anions was $100 \mathrm{~mm}$ made up in $20 \mathrm{~mm}-\beta-$ alanine sulphate, $\mathrm{pH} 3 \cdot 0 . \mathrm{pH}_{\text {in }}$ and $\Delta \psi$ were calculated from the distribution of radioisotopes as described in Methods. $\mathrm{O}, \mathrm{Na}_{2} \mathrm{SO}_{4} ; \Delta, \mathrm{NaCl} ; \bullet, \mathrm{NaBr} ; 0, \mathrm{NaNO}_{3} ; \triangle, \mathrm{NaI} ; \mathbf{\square}$, no salt added.

accumulate anions (Cox et al., 1979). At pH 0.94, respiration both in the absence and presence of uncoupler will be more sensitive to anions, because the $\Delta \psi$ in the absence of uncoupler will be $+70 \mathrm{mV}$ inside, and is projected to be approximately $+250 \mathrm{mV}$ inside in the presence of uncoupler (in both cases tending to accumulate anions). Sensitivity to anions is thus a pHdependent phenomenon: the lower the $\mathrm{pH}$ the greater the toxicity, as a result of the $\mathrm{pH}$ dependence of the magnitude and polarity of $\Delta \psi$. The $I_{50}$ values given in Table 1 were obtained from oxygen electrode traces of $\mathrm{Fe}$ (II) oxidation after the rates had stabilized, as described in the legend. Overall, the traces obtained for the effects of anions on $\mathrm{Fe}(\mathrm{II})$ oxidation are complex because order of addition, physiological state of the cells and length of preincubation time affect the oxidation rates, and these rates are often not linear. If cells are added to the medium containing the anion before substrate then the toxicity is greater, presumably because the cell has been exposed to the anion when unenergized. Uncoupler potentiates the inhibition. Some recovery of the oxidation rate may occur depending on the anion used, its concentration, the presence of uncoupler and extent of preincubation. These phenomena are illustrated in Fig. 1 for the anion $\mathrm{Br}^{-}$: trace $(a)$ is the control $\left(\mathrm{SO}_{4}^{2-}\right)$ and trace $(b)$ (note slower time base) shows the effect of preincubating cells with buffer and uncoupler, in the presence of $\mathrm{Br}^{-}$, before substrate addition. This is the most deleterious condition, presumably because the anion has had time to 
Table 2. Effects of organic acids on $p H_{\mathrm{in}}$ and $\Delta \psi$ in the absence and presence of DNP

Each value is the mean of 18 determinations. The cells were non-respiring and the concentration of the organic acids was $5 \mathrm{mM}$; the buffer was $20 \mathrm{~mm}$ - $\beta$-alanine sulphate, $\mathrm{pH} 3.0$. The measurements of $\Delta \mathrm{pH}$ and $\Delta \psi$ were calculated from the distribution of radioisotopes as described in Methods.

\begin{tabular}{|c|c|c|c|c|c|}
\hline \multirow[b]{2}{*}{ Species } & \multirow[b]{2}{*}{$\mathrm{p} K_{\mathrm{a}}$} & \multicolumn{2}{|c|}{-DNP } & \multicolumn{2}{|c|}{ +DNP } \\
\hline & & $\mathrm{pH}_{\mathrm{in}}$ & $\Delta \psi$ & $\mathrm{pH}_{\mathrm{in}}$ & $\Delta \psi$ \\
\hline $\begin{array}{l}\text { None } \\
\text { Proprionate } \\
\text { Acetate } \\
\text { Lactate } \\
\text { Chloroacetate } \\
\text { Pyruvate }\end{array}$ & $\begin{array}{l}4 \cdot 75 \\
4 \cdot 9 \\
3 \cdot 1 \\
2 \cdot 86 \\
2 \cdot 5\end{array}$ & $\begin{array}{l}5.9 \pm 0.12 \\
5.0 \pm 0.06 \\
5.0 \pm 0.06 \\
4.8 \pm 0.03 \\
4.2 \pm 0.04 \\
4.3 \pm 0.02\end{array}$ & $\begin{array}{r}131 \pm 2 \\
76 \pm 3 \\
82 \pm 2 \\
72 \pm 2 \\
65 \pm 2 \\
72 \pm 2\end{array}$ & $\begin{array}{l}5.6 \pm 0.1 \\
5.0 \pm 0.03 \\
5.0 \pm 0.04 \\
4.9 \pm 0.03 \\
4.3 \pm 0.07 \\
4.3 \pm 0.03\end{array}$ & $\begin{array}{r}136 \pm 3 \\
106 \pm 2 \\
117 \pm 2 \\
106 \pm 2 \\
85 \pm 2 \\
86 \pm 2\end{array}$ \\
\hline
\end{tabular}

accumulate inside before the onset of respiration. Trace $(c)$ shows the effects of adding the cells last to the incubation mixture (in the presence of DNP): in this case the inhibition is progressive, presumably as the anion is accumulated. Trace $(d)$ shows that in the absence of uncoupler $\mathrm{Br}^{-}$is not very toxic; the respiration rate is not linear because the preincubation may have allowed some anion to accumulate in the cytoplasm, but not enough to render the process irreversible so that the respiratory process can re-establish the $\Delta p$ and $\mathrm{pH}_{\text {in }}$ (hence the acceleration in rate).

The effect of the anions on the $\mathrm{pH}_{\mathrm{in}}$ as a function of time is shown in Fig. 2. It can be seen that all species tested, except $\mathrm{SO}_{4}^{2-}$, caused some acidification of the cell cytoplasm both in the absence and presence of DNP. In the absence of DNP only $\mathrm{I}^{-}$was very effective in collapsing $\mathrm{pH}_{\text {in }}$. The $\mathrm{pH}_{\text {in }}$ values obtained for $\mathrm{SO}_{4}^{2-}, \mathrm{Cl}^{-}, \mathrm{Br}^{-}$and $\mathrm{NO}_{3}^{-}$, in the absence of DNP did not fall further after $1 \mathrm{~h}$ (experiments were done for up to $6 \mathrm{~h}$ ). However, in the presence of $\mathrm{I}^{-}, \mathrm{pH}_{\text {in }}$ did continue to fall, reaching a low of $3.5\left(\mathrm{pH}_{\text {out }} 3.0\right)$ after $3 \mathrm{~h}$. It must be remembered that endogenous substrate reserves may help to maintain the $\mathrm{pH}_{\text {in }}$ by providing energy for $\mathrm{H}^{+}$and ion transport in the absence of uncoupler, and may be able to cope for a while if the rate of entry is not too great. In the presence of DNP the $\mathrm{pH}_{\text {in }}$ falls further and more rapidly. There are two reasons for this: firstly, the possible loss of any ATP from endogenous metabolism, and secondly, because in the presence of uncoupler the $\Delta \psi$ will be more positive inside, pulling in the anions. The uncoupler will also facilitate the cotransport of protons with the anion movement. In the absence of substrate the effect of uncoupler will be less dramatic than in the presence of substrate because $\Delta p$ is already much lower before uncoupler is added (cf. Table 1 and Fig. 2).

The effects of the anions on the $\Delta \psi$ in the presence and absence of DNP are also shown in Fig. 2. A comparison of the effects of the anions shows that the presence of DNP produces a larger $\Delta \psi$, positive inside, and potentiates the efficacy of the anions in collapsing the $\Delta \psi$. These results indicate that there is a predominating electrophoretic contribution to the distribution of the anions, in agreement with the findings in Table 1 and Fig. 1, and in contrast to the distribution of 'weak' acids which is unaffected by the presence of uncoupler (see below). The order of toxicity of the anions towards Fe(II) oxidation follows that of their efficacy in collapsing the $\mathrm{pH}_{\text {in }}$ suggesting that the inhibition arises from acidification of the cytoplasm. In addition, both the inhibition of substrate oxidation and the collapse of $\mathrm{pH}_{\text {in }}$ are potentiated by uncoupler.

To show, directly, that these anions distribute electrophoretically, we studied the accumulation in the cytoplasm of $\mathrm{NO}_{3}^{-}$. At an initial external concentration of $0 \cdot 1 \mathrm{mM} \mathrm{NO}-$ accumulation reached equilibrium after approximately $15 \mathrm{~min}$. Measurements were made in the presence of uncoupler, and under the conditions used (low concentration of permeant anion) the $\mathrm{pH}_{\text {in }}$ and the $\Delta \psi$ did not fall significantly, allowing an accumulation ratio for $\mathrm{NO}_{3}^{-}$of approximately 140 , representing a $\Delta \psi$ (calculated from the $\mathrm{NO}_{3}^{-}$distribution) of approximately $130 \mathrm{mV}$. The internal $\mathrm{NO}_{3}^{-}$concentration was calculated both directly from the amount of $\mathrm{NO}_{3}^{-}$ trapped in the matrix and indirectly from the decrease in concentration in the supernatant; the two values were in good agreement.

The acidification of the cytoplasm as a consequence of anion entry (at inhibitory concentrations of the anion) is due to the fact that the $\Delta \psi$ and $\Delta \mathrm{pH}$ are in balance; a drop in $\Delta \psi$ 


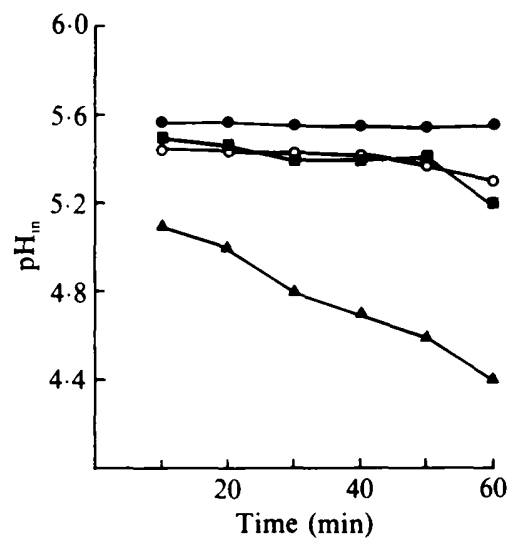

Fig. 3. Effects of complex organic acids on $\mathrm{pH}_{\mathrm{in}}$. Cells were suspended in $10 \mathrm{mM}-\mathrm{H}_{2} \mathrm{SO}_{4}, \mathrm{pH} 1 \cdot 8(\odot)$, $10 \mathrm{mM}-\mathrm{H}_{2} \mathrm{SO}_{4}+1 \mathrm{~mm}$-sodium oxalate, $\mathrm{pH} 1 \cdot 8(\Delta), 20 \mathrm{~mm}$ - $\beta$-alanine sulphate, pH $3.0(\mathrm{O})$, or $20 \mathrm{~mm}-\beta$ alanine sulphate $+10 \mathrm{~mm}$-sodium glutamate, $\mathrm{pH}$ 3-0 (ם). DNP $(25 \mu \mathrm{M})$ was present in all incubations. $\mathrm{pH}_{\mathrm{in}}$ was determined as described in Methods.

(inside positive) due to the movement of anions will mean that the $\Delta \mathrm{pH}$ will tend to be greater than the opposing $\Delta \psi$, and thus protons will enter until the two forces are again balanced. In the absence of a protonophore the entry of protons may be slow, and when coupled respiration is occurring respiration can remove these protons. Thus, the collapsing of $\Delta \psi$ by anions leads to the acidification of the cytoplasm either in the presence of high concentrations of the anions or when the cells are 'de-energized'. Although $T$. ferrooxidans is sensitive to anions, it is unusually resistant to heavy metal cations. Specific mechanisms of resistance may exist but a general mechanism for resistance may be the opposite of the anion case, i.e. non-specifically permeable cations may be excluded by the $\Delta \psi$, whereas in neutrophiles they may be accumulated by a $\Delta \psi$ of normal polarity.

\section{Effects of organic acids}

We studied the effects of a selected range of acids on $\Delta \mathrm{pH}$ and $\Delta \psi$ and on respiratory activity. In addition we studied the converse - the effects of $\Delta \mathrm{pH}$ and $\Delta \psi$ on the distribution of the acids and distinguished between the role of the $\Delta \mathrm{pH}$ and the $\Delta \psi$ in these phenomena. The organic acids used are listed in Table 2. The effect of the monobasic acids $(5 \mathrm{~mm})$ on the $\mathrm{pH}_{\mathrm{in}}$ and on the $\Delta \psi$ across the bacterial cytoplasmic membrane is also shown. The control value for $\mathrm{pH}_{\text {in }}$ obtained with chloroacetic acid as a probe is lower than when acetate was used as the probe $\left(\mathrm{pH}_{\text {in }} 6.5\right.$ and 6.2 in the absence and presence of DNP respectively), probably because chloroacetic acid affects $\mathrm{pH}_{\text {in }}$ through its larger accumulation ratio, but it was used because of its lower $\mathrm{p} K_{\mathrm{a}}$ (as explained in Methods). However, taking into account the effect of the probes themselves on $\Delta \mathrm{pH}$ and $\Delta \psi$, it can still be seen that all of the organic acids tested caused some acidification of the cell cytoplasm, proprionic acid being the least effective of this group, followed by acetic, lactic, pyruvic and chloroacetic acids. This sequence approximately follows the increase in predicted accumulation ratios (and decreasing $\mathrm{p} K_{\mathrm{a}}$ values). The time-course of the effects were followed between $2 \mathrm{~min}$ and $1 \mathrm{~h}$. In the case of all those monobasic acids tested the collapse of $\mathrm{pH}_{\text {in }}$ appears to occur within the first $10 \mathrm{~min}$ of incubation. The effects of organic acids on $\mathrm{pH}_{\text {in }}$ and $\Delta \psi$ when DNP is present are also shown in Table 2 . The protonophore did not potentiate the collapse of $\Delta \mathrm{pH}$ and $\Delta \psi$ in the presence of organic acids, in contrast to its effect in the presence of permeant anions. The more complex glutamic and oxalic acids were slower in their effects on $\Delta \mathrm{pH}$ and $\Delta \psi$. The effects of oxalate (two carboxyls), glutamate (two carboxyls, one amino group) and $\beta$-alanine (one carboxyl and one amino group) on the $\Delta \mathrm{pH}$ are shown in Fig. 3. The $\Delta \mathrm{pH}$ in the control $\left(10 \mathrm{mM}-\mathrm{H}_{2} \mathrm{SO}_{4}\right)$ and in the presence of oxalate were determined at $\mathrm{pH} \mathrm{1.8,} \mathrm{whereas} \mathrm{the} \mathrm{effects} \mathrm{of} \beta$-alanine sulphate and glutamate were determined at $\mathrm{pH} \mathrm{3.0.The}$ $\mathrm{pH}_{\text {in }}$ falls significantly in the presence of low concentrations of oxalic acid (1 mM) but more 
Table 3. Inhibition of respiration by organic acids

Buffer ( $20 \mathrm{~mm}$ - $\beta$-alanine sulphate, $\mathrm{pH} 3.0$ ) plus cells were preincubated for $10 \mathrm{~min}$ before addition of substrate $\left(5 \mathrm{mM}\right.$-ascorbate $/ 0 \cdot 1 \mathrm{mM}$-TMPD, or $\left.10 \mathrm{mM}-\mathrm{FeSO}_{4}\right)$, at $30^{\circ} \mathrm{C}$. The concentration of acids was $10 \mathrm{mM}$; that of DNP was $25 \mu \mathrm{M}$. Each value is the mean of five or more determinations. The respiration

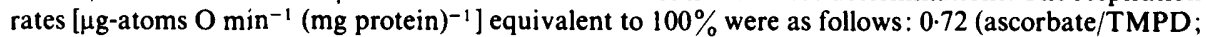
-DNP); 0.92 (ascorbate/TMPD; + DNP); 0.81 [Fe(II); -DNP]; 0.82 [Fe(II); + DNP].

\begin{tabular}{|c|c|c|c|c|c|}
\hline \multirow[b]{3}{*}{ Species } & \multirow{3}{*}{ Substrate ... } & \multicolumn{4}{|c|}{ Respiration rate (percentage of control) } \\
\hline & & \multicolumn{2}{|c|}{ Ascorbate/TMPD } & \multicolumn{2}{|c|}{$\mathrm{Fe}(\mathrm{II})$} \\
\hline & & -DNP & + DNP & -DNP & + DNP \\
\hline None & & 100 & 100 & 100 & 100 \\
\hline Proprionate & & 79 & 69 & 70 & 58 \\
\hline Acetate & & 63 & 54 & 68 & 78 \\
\hline Lactate & & 82 & 63 & 74 & 59 \\
\hline Chloroacetate & & 8 & 14 & 10 & 14 \\
\hline Pyruvate & & 16 & 36 & 34 & 40 \\
\hline
\end{tabular}

slowly than in the case of the monobasic acids (where collapse of $\mathrm{pH}_{\mathrm{in}}$ is complete after $10 \mathrm{~min}$ ). Theory predicts massive accumulation of oxalic acid into the cell cytoplasm. This slow effect may be because of slow equilibration with a chelated form of the oxalate (oxalate readily complexes with a range of cations). The distribution of glutamic acid is complicated by the amino group which will be positively charged and is likely to reduce non-specific membrane permeability, and may introduce an electrophoretic element into the distribution (this acid is not deleterious at these concentrations).

A number of reports cite specific interactions between the $\mathrm{Fe}(\mathrm{II}) / \mathrm{Fe}(\mathrm{III})$ couple and anions (Huffman \& Davidson, 1956; Tuttle \& Dugan, 1976; Tuttle et al., 1977). To determine the importance of these direct effects we also tested the action of the acids on the oxidation of the artificial substrate ascorbate with $N, N, N^{\prime}, N^{\prime}$-tetramethyl-p-phenylenediamine (TMPD). The results obtained both for Fe(II) and ascorbate/TMPD oxidation are complex because order of addition, physiological state of the cells and times of preincubation affect the oxidation rates, and these rates are generally not linear. However, the sensitivities to organic acids of oxidation of the two substrates by $T$. ferrooxidans parallel each other, indicating general rather than specific mechanisms. If the cells are added to the medium containing the organic acid before substrate then the toxicity is greater, presumably because the cell has been exposed to the acid when unenergized. Some recovery of the oxidation rate may occur depending on the organic acid used and extent of preincubation. The data shown in Table 3 are taken from oxygen electrode traces of substrate oxidation by $T$. ferrooxidans cells. The cells were preincubated with the organic acid for $10 \mathrm{~min}$ before addition of the substrate and the maximum oxidation rate was measured; this developed after a variable lag period. The most potent inhibitors both of $\mathrm{Fe}$ (II) and ascorbate/TMPD oxidation were chloroacetate and pyruvate. Proprionate, acetate and lactate inhibited to approximately similar extents. This order of toxicity approximately follows that of the efficacy of the acids in collapsing the $\mathrm{pH}_{\mathrm{in}}$, suggesting that the inhibition arises from acidification of the cytoplasm.

Cox et al. (1979) have shown that $T$. ferrooxidans respiring with either $\mathrm{Fe}(\mathrm{II})$ or ascorbate/TMPD at $\mathrm{pH} 3.0$ maintains a $\Delta \psi$ of $+40 \mathrm{mV}$; on the addition of DNP this falls to approximately $-180 \mathrm{mV}$. The effect of organic acids on respiration in the presence of DNP is shown in Table 3. The inhibition of respiration in the presence or absence of DNP was qualitatively similar. With DNP chloroacetate and pyruvate are less effective, probably because DNP does cause a small fall in $\mathrm{pH}_{\mathrm{in}}$, thus lowering the maximum accumulation ratio (e.g. if the $\mathrm{pH}_{\text {in }}$ falls from 6.5 to 6 then the maximum theoretical accumulation ratio of pyruvate falls from $2.4 \times 10^{3}$ to $7.6 \times 10^{2}$ ). If the anions could be accumulated electrophoretically then the large $\Delta \psi$, positive inside in the presence of DNP, would lead to greater accumulation and hence greater sensitivity. These results should be contrasted with the ability of DNP to potentiate the toxicity of inorganic anions, and indicate that there is no significant electrophoretic contribution to the 
distribution of the organic acids. If the distribution of the organic acids were significantly influenced by electrophoretic processes then their ability to inhibit $\mathrm{Fe}(\mathrm{II})$ and ascorbate/TMPD oxidation, and to be accumulated inside the cell, would be greatly potentiated by the addition of DNP.

We attempted to determine the specific site in the respiratory chain at which these acids inhibited respiration. To do this we studied the extent of oxidation/reduction of respiratory chain components during steady-state respiration. If a component is on the substrate [Fe(II)] side of the block it will become reduced relative to the control; if on the $\mathrm{O}_{2}$ side it will become oxidized. Comparisons of the optical difference spectra (at $77 \mathrm{~K}$; not shown) indicates that during steady-state respiration in the absence of inhibitor the cytochromes $c$ and $a_{1}$ are only partially reduced; however, during the residual respiration occurring in the presence of chloroacetic acid all of these cytochromes are extensively reduced. This indicates that the site of inhibition is on the $\mathrm{O}_{2}$ side of the cytochromes, i.e. at or close to the terminal $\mathrm{O}_{2}$ reduction reaction. This location of the first $\mathrm{pH}$-sensitive cytosolic site in the respiratory chain at the terminal step in the chain is in accord with the model of the $\mathrm{Fe}(\mathrm{II})$-oxidizing respiratory chain proposed by Ingledew et al. (1977). In this model most of the respiratory chain components are located periplasmically or on the external surface of the cytoplasmic membrane, except for the $\mathrm{O}_{2}$ reduction site.

The work reported in this paper was supported by SERC grant GR/D/54415. B. Alexander is a recipient of a CASE studentship. We are grateful to Mr L. Barnes of Shell UK PLC for helpful advice and discussions, and to J. Woodhall and S. Russell for their technical assistance.

\section{REFERENCES}

Addanki, S., Cahill, F. D. \& Sotos, J. F. (1968). Determination of intramitochondrial $\mathrm{pH}$ and intramitochondrial-extramitochondrial $\mathrm{pH}$ gradient of isolated heart mitochondria by the use of $5,5-$ dimethyl-2,4-oxazolidinedione. Journal of Biological Chemistry 243, 2337-2348.

Cobley, J. G. \& Haddock, B. A. (1975). The respiratory chain of Thiobacillus ferrooxidans: the reduction of cytochromes by $\mathrm{Fe}^{2+}$ and the preliminary characterization of rusticyanin a novel 'blue' copper protein. FEBS Letters 60, 29-33.

Cox, J. C., Nicholls, D. G. \& INGledew, W. J. (1979). Transmembrane electrical potential and transmembrane $\mathrm{pH}$ gradient in the acidophile Thiobacillus ferro-oxidans. Biochemical Journal 178, 195-200.

Dugan, P. R. \& Lundgren, D. G. (1965). Energy supply for the chemoautotroph Ferrobacillus ferrooxidans. Journal of Bacteriology 89, 825-833.

Huffman, R. E. \& Davidson, N. (1956). Kinetics of the ferrous iron-oxygen reaction in sulfuric acid solution. Journal of the American Chemical Society 78, 4836-4842.

INGLEDEW, W. J. (1982). Thiobacillus ferrooxidans. The bioenergetics of an acidophilic chemolithotroph. Biochimica et biophysica acta 683, 89-117.

INGLEDEW, W. J., CoX, J. C. \& Halling, P. J. (1977). A proposed mechanism for energy conservation during $\mathrm{Fe}^{2+}$ oxidation by Thiobacillus ferrooxidans; chemiosmotic coupling to net $\mathrm{H}^{+}$influx. FEMS Microbiology Letters 2, 193-197.

LAZAROFF, N. (1977). The specificity of the anionic requirement for iron oxidation by Thiobacillus ferrooxidans. Journal of General Microbiology 101, 85-91.
LAZAROFF, N. (1983). The exclusion of $\mathrm{D}_{2} \mathrm{O}$ from the hydration sphere of $\mathrm{FeSO}_{4} \cdot 7 \mathrm{H}_{2} \mathrm{O}$ oxidised by Thiobacillus ferrooxidans. Science 222, 1331-1334.

Matin, A., Wilson, B., Zychlinsky, E. \& Matin, M. (1982). Proton motive force and the physiological basis of delta $\mathrm{pH}$ maintenance in Thiobacillus acidophilus. Journal of Bacteriology 150, 582-591.

Mitchell, P. (1966). Chemiosmotic Coupling of Oxidative and Photosynthetic Phosphorylation. Bodmin, Cornwall: Glynn Research Limited.

NicholLS, D. G. (1974). The influence of respiration and ATP hydrolysis on the proton-electrochemical gradient across the inner membrane of rat liver mitochondria as determined by ion distribution. European Journal of Biochemistry 50, 305-315.

Razzell, W. E. \& Trussell, P. C. (1963). Isolation and properties of an iron-oxidizing Thiobacillus. Journal of Bacteriology 85, 595-603.

ROTTENBERG, H. (1979). The measurement of membrane potential and $\Delta \mathrm{pH}$ in cells, organelles, and vesicles. Methods in Enzymology 55, 547-569.

Rottenberg, H., Grunwald, T. \& Avron, M. (1972). Determination of $\Delta \mathrm{pH}$ in chloroplasts. 1. Distribution of $\left[{ }^{1+} \mathrm{C}\right] \mathrm{methylamine}$. European Journal of Biochemistry 25, 54-63.

Tuttle, J. H. \& Dugan, P. R. (1976). Inhibition of growth, iron, and sulfur oxidation in Thiobacillus ferrooxidans by simple organic compounds. Canadian Journal of Microbiology 22, 719-730.

Tuttle, J. H., Dugan, P. R. \& APEL, W. A. (1977). Leakage of cellular material from Thiobacillus ferrooxidans in the presence of organic acids. Applied and Environmental Microbiology 33, 459-469. 